\title{
Testosterone induces paternal behavior in sexually inexperienced males of Neotomodon alstoni (Rodentia: Muridae)
}

\author{
Juana Luis $^{1 *}$, Guillermo Ramos ${ }^{1}$, Martín Martínez-Torres ${ }^{1}$, Agustín Carmona ${ }^{2}$, Benita Cedillo ${ }^{3}$ \\ \& Jesús Delgado ${ }^{3}$ \\ 1. Laboratorio de Biología de la Reproducción, UMF, FES Iztacala, Universidad Nacional Autónoma de México, Av. de \\ los Barrios No. 1, CP 05490 Tlalnepantla, Estado de México, México; luisdc@unam.mx, guillermoramos@unam.mx, \\ martor@unam.mx \\ 2. Laboratorio de Biología Animal Experimental, Facultad de Ciencias, Universidad Nacional Autónoma de México, CP \\ 04510 México, Ciudad de México, México; agustincarmona@unam.mx \\ 3. Laboratorio de Psicología Experimental, FES Iztacala, Universidad Nacional Autónoma de México, Av. de los Barrios \\ No. 1, CP 05490 Tlalnepantla, Estado de México, México; cedillo_b@yahoo.com \\ * Correspondence
}

Received 28-III-2017. Corrected 10-VII-2017. Accepted 08-VIII-2017.

\begin{abstract}
The inhibition of infanticide can be considered a prerequisite for the onset of paternal behavior. Thus, hormones such as testosterone $(\mathrm{T})$ would be expected to mediate the inhibition of aggression toward pups and the onset of paternal care. However, the effect of $\mathrm{T}$ in onset of this behavior seems to depend of sexual experience. The aim of this study was to determine whether $T$ induces paternal behavior in sexually inexperienced males of the Mexican volcano mouse (Neotomodon alstoni). For this, 33 non-paternal males were selected based on paternal behavior tests. These non-paternal mice were organized in three groups: 10 males were castrated, 10 subjected to sham procedure, and 13 underwent castration and T replacement. After of these treatments, the males were again evaluated by a second paternal behavior test, and blood samples were obtained to measure plasma $\mathrm{T}$ levels by radioimmunoassay. Castrated males with T replacement changed their behavior; $46.2 \%$ of these males displayed paternal behavior despite $92.3 \%$ of these males having previously displayed aggressive behavior in the selection test. An increase in T facilitates the onset of paternal behavior in sexually inexperienced males of Mexican volcano mouse, as occurs in sexual experience males. These results support the hypothesis that an increase in $\mathrm{T}$ levels would be involved in the neuroendocrine mechanisms that suppress infanticide and promote the onset of parental behavior in Mexican volcano mice males. Future studies in this mouse will investigate whether $\mathrm{T}$ regulates the onset of paternal behavior via conversion to estradiol or whether both T metabolites are involved in its onset. Rev. Biol. Trop. 65 (4): 1419-1427. Epub 2017 December 01.
\end{abstract}

Key words: paternal behavior, testosterone, paternal tests, sexually inexperienced males, Neotomodon alstoni.

Male parental care is relatively rare among mammals and occurs in approximately $5 \%$ of all species (Kleiman \& Malcolm, 1981). Paternal care has primarily been observed in primates, carnivores and rodents (Elwood, 1983; Jennions \& Macdonald, 1994; Woodroffe \& Vincent, 1994).

Just as in females, males must inhibit their infanticidal behavior and become paternal before the birth of the pups to avoid hurting their own offspring (Hrdy 1979; Vom Saal
\& Howard, 1982; Hausfater \& Hrdy, 1984; Parmigiani \& Vom Saal, 1994). The transition from infanticidal to paternal behavior involved hormonal changes that may be triggered by stimuli such as copulation, female odours, and presence of pups (Brown 1985; Reburn \& Wynne-Edwards, 1999). Changes in the peripheral levels of prolactin and testosterone (T) have been associated with the display of paternal care (Wang \& De Vries 1993; Clark \& Galef 1999; Lonstein \& De Vries, 1999; Ziegler 
\& Snowdon, 2000; Ziegler, Wegner, Carlson, Lazaro-Perea, \& Snowdon, 2000; Hume \& Wynne-Edwards, 2005). These hormonal signals may cause neuroendocrine changes that modify the physiological state of an animal to respond positively to chemosensory cues from its pups (Brown, 1985; Vom Saal, 1985; Kennedy \& Elwood, 1988; Perrigo, Bryant, \& Vom Saal, 1990; Brown, Murdoch, Murphy, \& Moger, 1995; Reburn \& Wynne-Edwards, 1999; Dulac, O’Connell \& Wu, 2014).

The role of $\mathrm{T}$ has been included in previous reports for different species. In the dwarf hamster (Phodopus campbelli), male plasma $\mathrm{T}$ levels increase before the female gives birth and decrease after offspring is born (Reburn \& Wynne-Edwards, 1999). But, subsequent investigations have indicated that plasma $\mathrm{T}$ levels in this rodent, does not decrease when males engage in paternal care (Schum \& Wynne-Edwards, 2005). A decrease in T levels has also been observed in men when they become fathers (Burnham et al., 2003). In the cotton-top tamarin (Saguinus oedipus), a primate, urinary $\mathrm{T}$ levels remain elevated after parturition when males provide paternal care (Ziegler \& Snowdon, 2000). In the California mouse (Peromyscus californicus), $\mathrm{T}$ has been demonstrated to promote paternal care in sexually experienced males, whereas castration reduces paternal care (Trainor \& Marler, 2001). However, in rodents such as the dwarf hamster, although castration significantly reduces $\mathrm{T}$ concentration, paternal behavior is not affected (Hume \& Wynne-Edwards, 2005). In prairie voles (Microtus ochrogaster) one study reported that castration reduced paternal behavior (Wang \& De Vries, 1993), although a later study concluded that castration had no effect (Lonstein \& De Vries, 1999).

The Mexican volcano mouse is an endemic species to the Trans-Mexican Volcanic Belt at $2600-4500 \mathrm{~m}$ above sea level. When volcano mice are mated in a monogamous system, reproductive performance and offspring survival are higher than mice species in promiscuous mating systems. This rodent reproduces during June-September, yielding litter sizes from 1 to
6 young with a mode of 3 and an average of 2.7; the gestation period is approximately 27 days (Olivera, Ramírez-Pulido, \& Williams, 1986). In captivity, the male displays paternal care and exhibits all of the maternal behaviors of the female, with the exception of suckling (Luis, Carmona, Delgado, Cervantes, \& Cárdenas, 2000), and the father spends more time than the mother crouching with and grooming pups (Luis et al., 2004). Trainor and Marler (2002) have indicated that conflicting results of different studies regarding the role of $\mathrm{T}$ in paternal behavior, may be explained by the inclusion of sexually inexperienced males, because copulation is a factor that facilitates paternal care. In this rodent a positive correlation between $\mathrm{T}$ levels and the amount of paternal care was observed five days after birth (Luis et al. 2009). Also, T has previously been shown to induce paternal behavior in sexually experienced males that are aggressive or indifferent toward pups (Luis et al., 2012). Thus, the aim of this study was to determine whether $T$ induces paternal behavior in sexually inexperienced males of the Mexican volcano mouse (Neotomodon alstoni).

\section{MATERIAL AND METHODS}

Animals: Male Mexican volcano mice with 300 to 310 days of age (these mice live approximately five years under laboratory conditions) were used in this study. These were obtained from a colony kept at Facultad de Estudios Superiores Iztacala, UNAM, in Mexico City, at $2230 \mathrm{~m}$ above sea level, in March 2012. The mice were maintained on $12: 12$ hours light-dark cycle (onset light at 1800 hours) at an ambient temperature of $17-21{ }^{\circ} \mathrm{C}$, and were fed pellets for rodents (T2018S.15 Teklad Global 18 \% Protein Rodent, Harlan, Ciudad de México, México) and tap water ad libitum; the diet was supplemented with carrots once a week. At the beginning of the study, two or three mice of the same sex were housed in a polycarbonate cage $(32 \times 23 \times 15 \mathrm{~cm})$, the animals used in this study were selected according to their indifference or aggressiveness 
toward pups. The classification criteria for male behavior were as follows: male indifference was defined as sniffing the pups and then moving away; male aggressiveness involved sniffing and may attacking the pups by biting, when they are not withdrawn quickly; and male paternal behavior was indicated by sniffing, grooming and crouching over the pups. Males that spontaneously exhibited paternal behavior were not included because the aim of this study was to investigate whether $T$ can induce paternal care. Paternal behavior selection tests were performed 10 to 15 days before the beginning the experiment. All the experimental procedures were carried out in the course of 2012.

During the selection tests used to evaluate the behavior toward pups, each male was placed in a cage (with the same characteristics as the housing cage) with clean sawdust bedding, and after 10 minutes of acclimatization a foreign pup of the species, aged one to three days, was introduced to the cage. Forty sexually inexperienced males were subjected to screening test of paternal behavior, resulting in $33(82.5 \%)$ non-paternal and seven $(17.5 \%)$ paternal males. The non-paternal mice were organized in three groups: 10 males were castrated, 10 subjected to sham procedure, and 13 underwent castration and $\mathrm{T}$ replacement. The most aggressive mice were assigned to castration and $\mathrm{T}$ replacement, to prove conclusively the effect of $\mathrm{T}$ on the induction of paternal behavior. All of the experiments were performed in accordance with the ethical guidelines and technical specifications of the Mexican Official Norm for the Production, Care and Use of Laboratory Animals (Secretaría de Agricultura, Ganadería, Desarrollo Rural, Pesca y Alimentación, 2001) as well as the guidelines of the American Society of Mammalogists for animal care and use (Sikes $\&$ the Animal Care and Use Committee of the American Society of Mammalogists, 2016).

Castration procedure and $T$ replacement: Before surgery or the placement of $\mathrm{T}$ implant, mice were anesthetized $(33 \mathrm{mg} / \mathrm{kg}$ of xylazine and $33 \mathrm{mg} / \mathrm{kg}$ of ketamine). All of the surgical instruments that were used were sterile, and $70 \%$ alcohol was applied to disinfect the scrotum. A small midline incision was made, and the testes were exteriorized. The spermatic and blood vessels were tied with 6.0 silk sutures, and the testes were removed. The incision was then closed with 6.0 silk sutures. In the sham-operated mice, the skin of the scrotum was incised to bring the testes out and extend them back, and the incision was closed with sutures only. The implants were made with Silastic tubing (Silastic Laboratory Tubing, i.d.: $1.47 \mathrm{~mm}$; o.d.: $1.96 \mathrm{~mm}$ ) packed with $10 \mathrm{~mm}$ of testosterone propionate (Sigma-Aldrich, St. Louis, MO), and the ends were sealed with silicone. Six days after the surgeries, a $\mathrm{T}$ implant was placed under the skin of the back; these implants have been successfully used in rodents, e.g., California mouse, the Mongolian gerbil and the Mexican volcano mouse (Clark \& Galef, 1999; Trainor \& Marler, 2001; Luis et al., 2012). Behavioral tests were performed after seven to eight days of $\mathrm{T}$ replacement.

Paternal behavior test: The second paternal behavior test was performed following the same procedure as described above. When a male exhibited paternal care or indifference toward the pup, 15 minutes of observations were conducted. Pups were used once for testing and then returned to their parents. A single observer recorded the latency of the onset of paternal behavior (the length of time it took for the male to groom the pup) and the time spent engaged in these activities. The observations were performed between 11:00 to $14: 00$ hours; although the Mexican volcano mouse is nocturnal, it also shows activity during the light cycle under laboratory conditions (Olivera et al., 1986). The test was immediately terminated if the pup was attacked.

Blood sampling and testosterone assay: Immediately after the second paternal behavior test, blood samples were taken from the retroorbital sinuses of castrated males, sham-operated males and males that underwent castration 
with $\mathrm{T}$ replacement utilizing heparinized capillary tubes under light ether anesthesia. Blood samples were taken between 11:30 and 14:30 h. Plasma was separated by centrifugation and stored at $-40{ }^{\circ} \mathrm{C}$, and $\mathrm{T}$ analysis was performed by radioimmunoassay (RIA). The RIA was made in duplicate with a Siemens kit for total testosterone (Diagnostic Products Corporation, Los Angeles, CA, USA) with ${ }^{125} \mathrm{I}$ testosterone and a sensitivity of $40 \mathrm{pg} / \mathrm{mL}$. The intra-assay and inter-assay coefficients of variation were $5.32 \%$ and $7.16 \%$, respectively. Radioactivity was measured with a model 1282 Compugamma gamma counter (LKB-Wallac, Turku, Finland).

In sexually inexperienced male Mexican volcano mice, castration did not have any effect on behavior (i.e., the percentage of mice that behaved aggressively toward pups before and after this treatment was the same), thus we did not perform any statistical tests on the data from this treatment group. The proportion of males that changed their behavior from aggressive or indifferent to paternal after the sham operation or $\mathrm{T}$ replacement was contrasted using $\mathrm{McNe}$ mar's test. As this test considers paired binary response data, the response variables were a change in the behavior toward the pup and no change in the behavior toward the pup.

The concentrations of $\mathrm{T}$ in the plasma of castrated, sham-operated and castrated males with $\mathrm{T}$ replacement were analysed with a nonparametric Kruskal-Wallis test, which was used due to the non-normality of the data (AndersonDarling test, $\mathrm{P}<0.05)$. A Bonferroni correction for multiple testing was applied for the pairwise comparisons, and $\mathrm{T}$ levels were correlated with time spent by paternal males crouching and grooming using Spearman's correlation analysis. Statistical analyses were performed using SPSS version 21.0.

\section{RESULTS}

Castration did not have any effect on the behavior of sexually inexperienced male Mexican volcano mice; i.e., the percentage of mice that behaved aggressively toward pups before and after this treatment was the same (Table 1). In sham-operated males, aggression decreased upon the second exposure to a pup, but no significant differences were observed $(\mathrm{P}>0.05$, Table 1). However, castrated males with $\mathrm{T}$ replacement changed their behavior: $46.2 \%$ of these males displayed paternal behavior despite $92.3 \%$ were aggressive in the first selection test. In addition, two males changed their behavior from aggressive toward pups to indifferent, increasing the percentage from $7.7 \%$ to $23.1 \%(\mathrm{P}<0.05$, Table 1$)$.

Mice exhibited paternal behavior with a latency of $0.16 \pm 0.12$ minutes. The paternal behaviors exhibited by these males were crouching over pups, grooming, retrieval and defence of the pups (Fig. 1). Crouching: male bows its body to form a concavity in the ventral region, under which it places the pups. Grooming: male licks the body of the pup, mainly genital region. Sniffing: male approaches the pup until touch it, rhythmically moving

TABLE 1

Testosterone and onset paternal behavior in the Mexican volcano mouse Neotomodon alstoni

\begin{tabular}{cccccc} 
Test paternal behavior before the treatment & \multirow{2}{*}{ Treatment } & \multicolumn{2}{c}{ Test paternal behavior afterthe treatment } \\
\cline { 2 - 6 } Aggressive & Indifferent & & Aggressive & Indifferent & Paternal \\
$50.0 \%$ & $50.0 \%$ & Castration & $50.0 \%$ & $50.0 \%$ & $0.0 \%$ \\
$\mathrm{n}=5$ & $\mathrm{n}=5$ & $\mathrm{n}=5$ & $\mathrm{n}=5$ & \\
$40.0 \%$ & $60.0 \%$ & Sham-castration & $30.0 \%$ & $70.0 \%$ & $0.0 \%$ \\
$\mathrm{n}=4$ & $\mathrm{n}=6$ & $\mathrm{n}=3$ & $\mathrm{n}=7$ & \\
$92.3 \%$ & $7.7 \%$ & Castration $+\mathrm{T}$ & $30.7 \%$ & $23.1 \%$ & $46.2 \%$ \\
$\mathrm{n}=12$ & $\mathrm{n}=1$ & $\mathrm{n}=4$ & $\mathrm{n}=3$ & $\mathrm{n}=6$ \\
\hline
\end{tabular}

Behaviors displayed by sexually inexperienced males Mexican volcano mouse before and after treatments. 


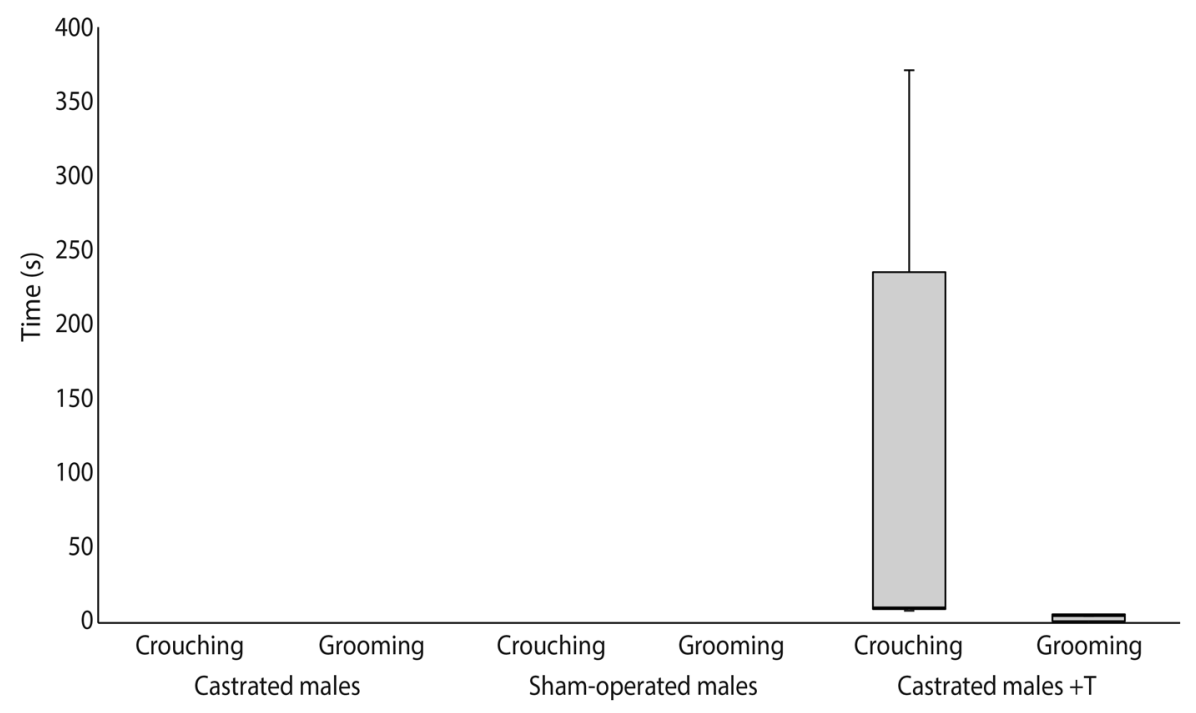

Fig. 1. Crouching over pups and grooming displayed by sexually inexperienced male Mexican volcano mice, Neotomodon alstoni. Data are presented as medians.

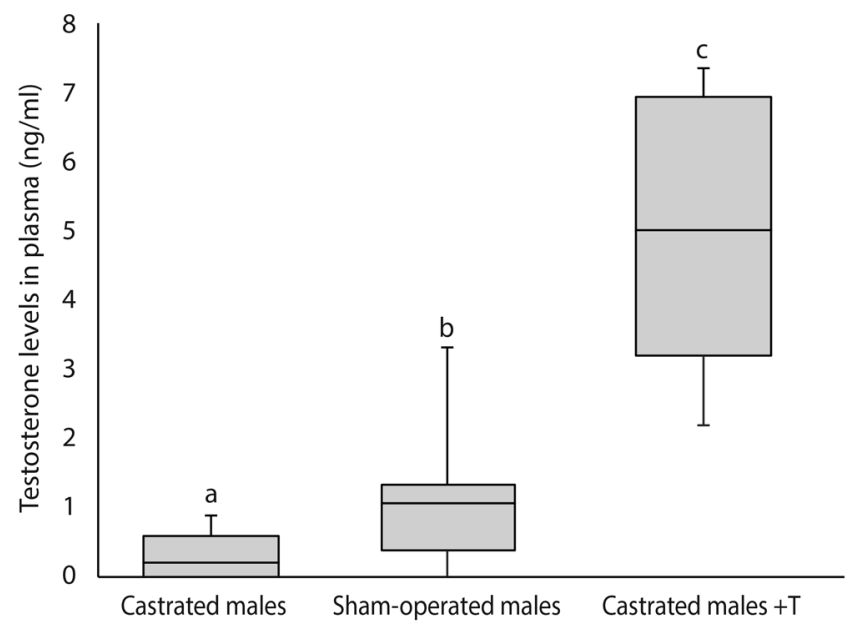

Fig. 2. Plasma T levels in sexually inexperienced male Mexican volcano mice, Neotomodon alstoni. Differences between groups are indicated by different letters above the bars. Data are presented as medians.

the nose and the vibrissae. Pup retrieval: the male returns the pups to the nest in his mouth. Defense of pups: when an object to remove the pup from the cage is introduced, the male attacks and bites the object.

The plasma $\mathrm{T}$ levels differed significantly between castrated males, sham-operated males and castrated males with $\mathrm{T}$ replacement $\left(\mathrm{H}_{2}=\right.$ $22.19, \mathrm{P}=0.01$, Fig. 2). The pair-wise contrast showed that plasma $\mathrm{T}$ levels in castrated males with $\mathrm{T}$ replacement were higher than those of sham-operated and castrated males, and castrated males had significantly lower $\mathrm{T}$ levels than sham-operated males (Bonferroni $\mathrm{P}=0.017$ ). 
Plasma T levels were not significantly correlated with time spent crouching over and grooming pups $(\mathrm{P}=0.92)$

\section{DISCUSSION}

Castrated and sham-operated males did not display any significant change in their behavior toward pups, but $46.2 \%$ of sexually inexperienced, castrated males treated with $\mathrm{T}$ replacement therapy exhibited paternal behavior despite being indifferent toward pups or displaying infanticidal behavior before treatment. The paternal males in this study provided the same care to pups as sexually experienced males (Luis et al. 2012), consequently these results showed that the inductive effects of $\mathrm{T}$ in the paternal behavior of the Mexican volcano mouse are independent of sexual experience. However, it is possible that the effects of $\mathrm{T}$ on paternal behavior could be enhanced by the paternal experience, as several studies have shown that females with maternal experience are more responsive to pups than first time females (Stolzenberg \& Rissman, 2011; Stolzenberg, Stevens \& Rissman, 2012).

The fact that all paternal males had higher $\mathrm{T}$ levels than non-paternal males supports the hypothesis that an increase in $\mathrm{T}$ levels would be involved in the neuroendocrine mechanisms that suppress infanticidal behavior and promote the onset of parental behavior in the Mexican volcano mouse. An increase in T levels also stimulates paternal behavior in the California mouse and the bank vole (Myodes glareolus), a rodent native to Great Britain (Trainor \& Marler, 2001; Gromov \& Osadchuk, 2013).

An increase in $\mathrm{T}$ levels also triggers the onset of paternal behavior in the Mongolian gerbil (Meriones unguiculatus); aggressive, sexually inexperienced males that received $\mathrm{T}$ implants after castration stopped being aggressive and became paternal. In this rodent, however, the $\mathrm{T}$ seems to regulate paternal behavior through estrogenic and androgenic pathways because estradiol and dihydrotestosterone inhibit infanticidal behavior and promote paternal behavior. As in the Mexican volcano mouse, paternal Mongolian gerbil males had higher $\mathrm{T}$ levels than non-paternal males (Martínez, et al., 2015).

Plasma $\mathrm{T}$ concentrations did not correlate with the time spent by males crouching and grooming pups, which is probably because the $\mathrm{T}$ released from the implants varied over a considerable range, surpassing physiological $\mathrm{T}$ concentrations $(1.5-2.1 \mathrm{ng} / \mathrm{ml})$ observed in the Mexican volcano mouse in a reproductive cycle (Luis et al., 2009).

Under natural conditions, copulation may shift male aggressive behavior toward paternal behavior because copulation increase the plasma T levels of male mammals (Frijakamel, Mock, \& Franckel, 1975, Maruniak \& Bronson, 1976; Coquelin \& Bronson, 1979; Bonilla, Vázquez-Palacios, Arteaga-Silva, \& Retana-Márquez, 2006; Roney, Lukaszewski, \& Simmons, 2007). In the California mouse, one-third of mated males showed paternal behavior 24 hours after copulation (Gubernick, Schneider, \& Jeannotte, 1994). In the Mongolian gerbil the $100 \%$ of virgin aggressive males transited to paternal after the copula, this transition was associated to an increase in $\mathrm{T}$ (data unpublished).

The results of this study also showed that the experimental induction of paternal behavior, similar to maternal behavior, requires high concentrations of hormones. In virgin ovariectomized female laboratory rats, 2 weeks of exposure to small $\mathrm{E}_{2}$ implants of 1 or $2 \mathrm{~mm}$ did not affect maternal responsiveness, whereas large 10-mm $\mathrm{E}_{2}$ implants stimulated maternal behavior (Bridges, 1984). Similarly, a dose of $100 \mu \mathrm{g} / \mathrm{kg}$ of oestradiol benzoate triggered the onset of maternal behavior in virgin females, but doses of $20 \mu \mathrm{g} / \mathrm{kg}$ were ineffective (Siegel \& Rosenblatt, 1975).

In the Mexican volcano mouse, the transition of non-paternal male to paternal was associated to an increase in $\mathrm{T}$ concentration. This finding supports the hypothesis that males, similar to females, undergo neuroendocrine changes in their transition to fatherhood (Saltzman \& Ziegler, 2014). The increase in T is also associated with male-male aggressive 
encounters and mating, suggesting that the social context may influence the functional consequences of changes in T levels (Gleason, Fuxajager, Oyegbile, \& Marler, 2009).

An increase in $\mathrm{T}$ facilitates the onset of paternal behavior in sexually inexperienced males of the Mexican volcano mouse, as occurs in sexual experience males, which suggests that the onset of paternal behavior is other social behavior that depends on an increase of this hormone.

Future studies in this mouse will investigate whether $\mathrm{T}$ regulates the onset of paternal behavior via conversion to estradiol, as is the case in the California mouse, or whether both $\mathrm{T}$ metabolites are involved in its onset, as in the Mongolian gerbil.

\section{ACKNOWLEDGMENTS}

This research was supported by Programa de Apoyo a Proyectos de Investigación e Innovación Tecnológica (IN213317) of Universidad Nacional Autónoma de México. We thank Carmen Álvarez Rodriguez and Pedro Medina Granados for his valuable assistance in this study. We express our gratitude to the reviewers for their valuable comments.

\section{RESUMEN}

La testosterona induce conducta paterna en machos sin experiencia sexual del ratón Mexicano de los volcanes Neotomodon alstoni (Rodentia: Muridae). La inhibición del infanticidio es necesaria en el inicio de la conducta paterna, así hormonas como la testosterona (T) pueden mediar la transición de machos agresivos a paternales. Sin embargo, el efecto de la T en el inicio de la conducta paterna parece depender de la experiencia sexual. El objetivo de este estudio fue determinar si $\mathrm{T}$ induce la conducta paterna en machos sin experiencia sexual del ratón Neotomodon alstoni. A través de pruebas de conducta paterna fueron seleccionados 33 machos no paternales; 23 fueron castrados bilateralmente, de los cuales a 13 se les colocó implante de T y 10 no recibieron ningún tratamiento. Otros 10 machos fueron sometidos a simulación del procedimiento. Después de los tratamientos, se realizaron nuevamente pruebas de conducta paterna para determinar cambios en la conducta de los machos hacia las crías. Enseguida se extrajeron muestras sanguíneas, para cuantificar los niveles de $\mathrm{T}$ en plasma, por radioinmuensayo.
El $46.2 \%$ de los machos castrados que recibieron implantes de $\mathrm{T}$ exhibieron conducta paterna, a pesar de que antes de la administración de esta hormona, el $92.3 \%$ fueron agresivos con las crías. Los machos que transitaron a paternales tuvieron concentraciones de T significativamente más altas que los machos con castración simulada. Un incremento en $\mathrm{T}$ facilita el inicio de la conducta paterna en machos sexualmente inexpertos del ratón Neotomodon alstoni. Estos resultados apoyan la hipótesis que un incremento en T está involucrado en los mecanismos neuroendócrinos que inhiben la agresión hacia las crías y facilitan el inicio de la conducta paterna. Investigaciones futuras deben enfocarse a establecer la función de ambos metabolitos de la $\mathrm{T}$ en la regulación de la conducta paterna de este ratón.

Palabras clave: conducta paterna, testosterona, pruebas de conducta paterna, machos sin experiencia sexual, Neotomodon alstoni.

\section{REFERENCES}

Bonilla, J., Vázquez-Palacios, G., Arteaga-Silva, M., \& Retana-Márquez, S. (2006). Hormonal responses to different sexually related conditions in male rats. Hormones and Behavior, 49, 376-382.

Bridges, S. R. (1984). A quantitative analysis of the roles of dosage, sequence, and duration of estradiol and progesterone exposure in the regulation of maternal behavior in the rat. Endocrinology, 114(3), 930-40.

Brown, R. E. (1985). Hormones and paternal behaviour in vertebrates. American Zoologist, 25, 895-910.

Brown, R. E., Murdoch, T., Murphy, P. R., \& Moger, W. H. (1995). Hormonal responses of male gerbils to stimuli from their mate and pups. Hormones and Behavior, 29, 474-491.

Burnham, T. C., Chapman, J. F., Gray, P. B., McIntyre, M. H., Lipson, S. F., \& Ellison, P. T. (2003). Men in committed, romantic relationships have lower testosterone. Hormones and behavior, 44, 119-122.

Clark, M. M., \& Galef, B. G. (1999). A testosterone mediated trade-off between parental and sexual effort in male Mongolian gerbils (Meriones unguiculatus). Journal of Comparative Psychology, 113, 338-395.

Coquelin, A., \& Bronson, F. H. (1979). Release of luteinizing hormone in male mice during exposure to females: habituation of the response. Science, 206, 1094-1101.

Dulac, C., O’Connell, A. L., \& Wu, Z. (2014). Neural control of maternal and paternal behaviors. Science, 345(6198), 765-770.

Elwood, R. W. (1983). Paternal care in rodents. New York: John Wiley. 
Frijakamel, E., Mock, W. W., \& Frankel, I. A. (1975). Alterations in plasma concentrations, $\mathrm{LH}$ and prolactin associated with mating in the male rat. Hormones and Behavior, 6, 277-288.

Gleason, D. E., Fuxajager, J. M., Oyegbile, O. T., \& Marler, A. C. (2009). Testosterone release and social context: When it occurs and why. Frontiers in Neuroendocrinology, 30, 460-469.

Gromov, V. S., \& Osadchuk, L. V. (2013). Parental care and testosterone in males of the bank vole (Myodes glareolus): Sensitization and androgenic stimulation of paternal behavior. The Biological Bulletin, 40(1), 114-118.

Gubernick, D. J., Schneider, A. K., \& Jeannotte, A. L. (1994). Individual differences, in the mechanism underling the onset and maintenance of parental behaviour and the inhibition of infanticide in the monogamous biparental California mouse Peromyscus californicus. Behavioral Ecology and Sociobio$\log y, 34,225-231$.

Hausfater, G., \& Hrdy, S. B. (1984). Infanticide: comparative and evolutionary perspectives. New York: Aldine.

Hrdy, S. B. (1979). Infanticide among animals: a review, classification and examination of the implications for the reproductive strategies of females. Ethology and Sociobiology, 1, 13-40.

Hume, J. M., \& Wynne-Edwards, K. E. (2005). Castration reduces male testosterone, estradiol, and territorial aggression, but no paternal behavior in parental dwarf hamster (Phodopus campbelli). Hormones and Behavior, 48, 303-310.

Jennions, M. D., \& Macdonald, D. W. (1994). Cooperate breeding in mammals. Trends in Ecology and Evolution, 9, 89-93.

Kennedy, H. F., \& Elwood, R. W. (1988). Strain differences in the inhibited of infanticide in male mice (Mus musculus). Behavioral and Neural Biology, 50, 349-353.

Kleiman, D. G., \& Malcolm, J. R. (1981). The evolution of male parental investment in mammals. In D. J. Gubernick, \& H. P. Klopfer (Eds.), Parental care in mammals (pp. 347-387). New York: Plenum Press.

Lonstein, J. S., \& De Vries, G. J. (1999). Sex differences in the parental behaviour of adult virgin prairie voles: Independence from gonadal hormones and vasopressin. Journal of Neurology, 11, 441-449.

Luis, J., Cadena, C., Zedillo, B., Reyes, J., Ramos, G., \& Martínez, M. (2012). Testosterone replacement induced paternal behaviour in the Mexican Volcano mouse Neotomodon alstoni (Rodentia: Muridae). Ethology Ecology and Evolution, 24(3), 275-283.

Luis, J., Carmona, A., Delgado, J., Cervantes, F. A., \& Cárdenas, R. (2000). Parental behavior of the volcano mouse, Neotomodon alstoni (Rodentia: Muridae), in captivity. Journal of Mammalogy, 81, 600-605.

Luis, J., Cervantes, F. A., Martínez-Torres, M., Cárdenas, R., Delgado, J., \& Carmona, A. (2004). Male influence on maternal behavior and offspring of captive Volcano mice (Neotomodon alstoni) from México. Journal of Mammalogy, 85(2), 268-272.

Luis, J., Ramírez, L., Carmona, A., Ortíz, G., Delgado, J., \& Cárdenas, R. (2009). Paternal behavior and testosterone plasma levels in the volcano mouse Neotomodon alstoni (Rodentia:Muridae). Revista de Biología Tropical, 57(1), 433-439.

Marumiak, J. A., \& Bronson, F. A. (1976). Gonadotropin responses of male mice to female urine. Endocrinology, 99, 963-969.

Martínez, A., Ramos, G., Martínez-Torres, M., Nicolás, L., Carmona, A., Cárdenas, M., \& Luis, J. (2015). Paternal behavior in the Mongolian gerbil (Meriones unguiculatus): Estrogenic and androgenic regulation. Hormones and Behavior, 71, 91-95.

Olivera, J., Ramírez-Pulido, J., \& Williams, S. 1986. Reproducción de Peromyscus (Neotomodon) alstoni (Mammalia: Muridae) en condiciones de laboratorio. Acta Zoológica Mexicana, 16, 1-27.

Parmigiani, S., \& Vom Saal, F. S. (1994). Prenatal gonadal influences on mouse sociosexual behaviours. In S. Parmigiani, \& F. S. Vom Saal (Eds.), Infanticide and parental care (pp. 43-72). London: Harwood Academic.

Perrigo, G., Bryant, W. C., \& Vom Saal, F. S. (1990). Individual variation in the neural timing of infanticide and parental behavior in house mice. Physiology and Behavior, 50, 287-296.

Reburn, C. J., \& Wynne-Edwards, K. E. (1999). Hormonal changes in males of naturally biparental and uniparental mammals. Hormones and Behavior, $35,163-176$.

Roney, J. R., Lukaszewski, A. W., \& Simmons, Z. L. 2007. Rapid endocrine responses of young men to social interactions with young women. Hormones and Behavior, 52, 326-333.

Saltzman, W., \& Ziegler, T. E. (2014). Functional significance of hormonal changes in mammalian fathers. Journal of Neuroendocrinology, 26, 685-696.

Schum, E., \& Wynne-Edwards, E. K. 2005. Estradiol and progesterone in paternal and non-paternal hamsters (Phodopus) becoming fathers: conflict with hypothesized roles. Hormones and Behavior, 47, 410-418.

Secretaría de Agricultura, Ganadería, Desarrollo Rural, Pesca y Alimentación. 2001. Norma Oficial Mexicana NOM-062-ZOO-1999. Especificaciones técnicas para la producción, cuidado y uso de los animales de laboratorio. Diario Oficial de la Federación, 75, 113-160 
Siegel, I. H., \& Rosenblatt, S. J. 1975. Estrogen-induced maternal behavior in hysterectomized-ovariectomized virgin rats. Physiology and Behavior, 14, 465-471.

Sikes, R. S., \& the Animal Care and Use Committee of the American Society of Mammalogists. (2016). Guidelines of the American Society of Mammalogists for the use of wild mammals in research and education. Journal of Mammalology, 97(3), 663-688.

Stolzenberg, S. D., \& Rissman, F. E. (2011). Oestrogen-independent, experienced-induced maternal behaviour in female mice. Journal of Neuroendocrinology, 23(4), 345-354.

Stolzenberg, S. D., Stevens, S. J., \& Rissman, F. E. (2012) Experienced-facilitated improves in pup retrieval, evidence for a epigenetic effect. Hormones and Behavior, 62(2), 128-135.

Trainor, B. C., \& Marler, C. A. (2001). Testosterone, paternal behavior and aggression in the monogamous California mouse (Peromyscus californicus). Hormones and Behavior, 40, 32-42.

Trainor, B. C., \& Marler, C. A. (2002). Testosterone promotes paternal behaviour via conversion to oestrogen in a monogamous mammal. Proceedings of the Royal Society of London B, 269, 823-829.
Vom Saal, F. S. (1985). Time-contingent change in infanticide and parental behavior induced by ejaculation in male mice. Physiology and Behavior, 34, 7-15.

Vom Saal, F. S., \& Howard, L. S. (1982). The regulation of infanticide and parental behavior: implications for reproductive success in male mice. Science, $215,1270-1272$.

Wang, Z., \& De Vries, G. J. (1993). Testosterone effects on parental behavior and vasopressin immunoreactive projections in prairie voles (Microtus ochrograster). Brain Research, 631, 156-160.

Woodroffe, R., \& Vincent, A. (1994). Mothers's little helpers: patterns of male care in mammals. Trends in Ecology and Evolution, 9, 294-297.

Ziegler, T. E., \& Snowdon, C. T. (2000). Preparental hormone levels and parenting experience in male cotton-top tamarins, Saguinus Oedipus. Hormones and Behavior, 38, 159-167.

Ziegler, T. E., Wegner, F. H., Carlson, A. A., Lazaro-Perea, C., \& Snowdon, C. T. (2000). Prolactin levels during the periparturitional period in the biparental cottontop tamarin (Saguinus oedipus): interactions with gender androgen levels and parenting. Hormones and Behavior, 38, 111-122. 